\title{
Front Matter: Volume 8860
}

, "Front Matter: Volume 8860," Proc. SPIE 8860, UV/Optical/IR Space Telescopes and Instruments: Innovative Technologies and Concepts VI, 886001 (22 October 2013); doi: 10.1117/12.2046455

SPIE Event: SPIE Optical Engineering + Applications, 2013, San Diego, California, SPIE. United States 


\section{PROCEEDINGS OF SPIE}

\section{UV/Optical/IR Space Telescopes and Instruments: Innovative Technologies and Concepts VI}

Howard A. MacEwen

James B. Breckinridge

Editors

25-26 August 2013

San Diego, California, United States

Sponsored and Published by

SPIE 
The papers included in this volume were part of the technical conference cited on the cover and title page. Papers were selected and subject to review by the editors and conference program committee. Some conference presentations may not be available for publication. The papers published in these proceedings reflect the work and thoughts of the authors and are published herein as submitted. The publisher is not responsible for the validity of the information or for any outcomes resulting from reliance thereon.

Please use the following format to cite material from this book:

Author(s), "Title of Paper," in UV/Optical/IR Space Telescopes and Instruments: Innovative Technologies and Concepts VI, edited by Howard A. MacEwen, James B. Breckinridge, Proceedings of SPIE Vol. 8860 (SPIE, Bellingham, WA, 2013) Article CID Number.

ISSN: 0277-786X

ISBN: 9780819497109

Published by

SPIE

P.O. Box 10, Bellingham, Washington 98227-0010 USA

Telephone +1 3606763290 (Pacific Time) · Fax +1 3606471445

SPIE.org

Copyright @ 2013, Society of Photo-Optical Instrumentation Engineers.

Copying of material in this book for internal or personal use, or for the internal or personal use of specific clients, beyond the fair use provisions granted by the U.S. Copyright Law is authorized by SPIE subject to payment of copying fees. The Transactional Reporting Service base fee for this volume is $\$ 18.00$ per article (or portion thereof), which should be paid directly to the Copyright Clearance Center (CCC), 222 Rosewood Drive, Danvers, MA 01923. Payment may also be made electronically through CCC Online at copyright.com. Other copying for republication, resale, advertising or promotion, or any form of systematic or multiple reproduction of any material in this book is prohibited except with permission in writing from the publisher. The CCC fee code is 0277-786X/13/\$18.00.

Printed in the United States of America.

Publication of record for individual papers is online in the SPIE Digital Library.

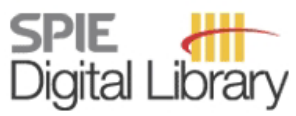

SPIEDigitalLibrary.org

Paper Numbering: Proceedings of SPIE follow an e-First publication model, with papers published first online and then in print and on CD-ROM. Papers are published as they are submitted and meet publication criteria. A unique, consistent, permanent citation identifier (CID) number is assigned to each article at the time of the first publication. Utilization of CIDs allows articles to be fully citable as soon as they are published online, and connects the same identifier to all online, print, and electronic versions of the publication. SPIE uses a six-digit CID article numbering system in which:

- The first four digits correspond to the SPIE volume number.

- The last two digits indicate publication order within the volume using a Base 36 numbering

system employing both numerals and letters. These two-number sets start with 00, 01, 02, 03, 04, $05,06,07,08,09,0 A, 0 B \ldots 0 Z$, followed by 10-1Z, 20-2Z, etc.

The CID Number appears on each page of the manuscript. The complete citation is used on the first page, and an abbreviated version on subsequent pages. Numbers in the index correspond to the last two digits of the six-digit CID Number. 


\section{Contents}

ix Conference Committee

xi Introduction

\section{SESSION 1 JWST}

886004 The JWST science instrument payload: mission context and status [8860-3]

M. A. Greenhouse, NASA Goddard Space Flight Ctr. (United States)

886005 Principal components analysis of a JWST NIRSpec detector subsystem [8860-4]

B. J. Rauscher, NASA Goddard Space Flight Ctr. (United States); R. G. Arendt, CRESST/UMBC/GSFC (United States); D. J. Fixsen, CRESST/UMd/GSFC (United States); M. A. Greenhouse, NASA Goddard Space Flight Ctr. (United States); M. Lander, Raytheon/GSFC (United States); D. Lindler, Sigma Space Corp./GSFC (United States); M. Loose, Markury Scientific, Inc. (United States); S. H. Moseley, D. B. Mott, Y. Wen, D. V. Wilson, C. Xenophontos, NASA Goddard Space Flight Ctr. (United States)

\section{SESSION 2 LARGE UVOIR SPACE TELESCOPES}

886006 Engineering specifications for large aperture UVO space telescopes derived from science requirements [8860-6]

H. Stahl, NASA Marshall Space Flight Ctr. (United States); M. Postman, Space Telescope Science Institute (United States); W. Smith, NASA Marshall Space Flight Ctr. (United States)

886007 The High-ORbit Ultraviolet-visible Satellite, HORUS [8860-7]

P. A. Scowen, Arizona State Univ. (United States); B. Cooke, Jet Propulsion Lab. (United States); M. Beasley, Planetary Resources, Inc. (United States); O. Siegmund, Lawrence Berkeley National Lab. (United States)

\section{SESSION 3 SPACE TELESCOPE CONCEPTS}

886009 In-space infrastructures and the Modular Assembled Space Telescope (MAST) [8860-9] H. A. MacEwen, Reviresco LLC (United States)

$88600 \mathrm{~A}$ Advancing toward far-infrared interferometry in space through coordinated international efforts [8860-10]

D. Leisawitz, NASA Goddard Space Flight Ctr. (United States); A. Baryshev, SRON Netherlands Institute for Space Research (Netherlands) and Univ. of Croningen (Netherlands); M. J. Griffin, Cardiff Univ. (United Kingdom); F. P. Helmich, SRON Netherlands Institute for Space Research (Netherlands) and Univ. of Corningen (Netherlands); R. J. Ivison, UK Astronomy Technology Ctr. (United Kingdom); S. A. Rinehart, NASA Goddard Space Flight Ctr. (United States); G. Savini, Univ. College London (United Kingdom); H. Shibai, Osaka Univ. (Japan) 
$8860 \mathrm{OB}$ Optical design and active optics for next generation space telescopes [8860-11]

V. Costes, D. Laubier, P. Darré, L. Perret, Ctr. National d'Études Spatiales (France)

8860 OC Compact infrared camera (CIRC) for earth observation adapting athermal optics [8860-12] E. Kato, H. Katayama, M. Naitoh, M. Harada, R. Nakamura, Japan Aerospace Exploration Agency (Japan); K. Nakau, Hokkaido Univ. (Japan); R. Sato, Japan Aerospace Exploration Agency (Japan)

8860 OD A small space telescope to conduct a large spectroscopic survey of galaxies [8860-13] S. R. Heap, Q. Gong, NASA Goddard Space Flight Ctr. (United States); T. Hull, The Univ. of New Mexico (United States); J. Kruk, L. Purves, NASA Goddard Space Flight Ctr. (United States); M. Robberto, Space Telescope Science Institute (United States)

\section{SESSION 4 WFIRST/EUCLID}

8860 OE Wide-Field Infrared Survey Telescope (WFIRST) 2.4-meter mission study (Invited Paper) [8860-14]

D. Content, NASA Goddard Space Flight Ctr. (United States); K. Aaron, Jet Propulsion Lab. (United States); L. Abplanalp, Exelis Inc. (United States); K. Anderson, R. Capps, Z. Chang, J. Dooley, Jet Propulsion Lab. (United States); R. Egerman, Exelis Inc. (United States); R. Goullioud, D. Klein, Jet Propulsion Lab. (United States); J. Kruk, NASA Goddard Space Flight Ctr. (United States); G. Kuan, Jet Propulsion Lab. (United States); M. Melton, J. Ruffa, NASA Goddard Space Flight Ctr. (United States); M. Underhill, D. Van Buren, Jet Propulsion Lab. (United States)

8860 OF Wide field instrument preliminary design for the Wide Field Infra-Red Survey Telescope [8860-15]

D. A. Content, NASA Goddard Space Flight Ctr. (United States); N. V. Armani, SGT, Inc. (United States); C. L. Baker, NASA Goddard Space Flight Ctr. (United States); C. E. Jackson, SGT, Inc. (United States); D. M. Kahle, J. W. Kruk, J. P. Lehan, SGT, Inc. (United States) M. E. Melton, E. Mentzell, J. J. Miko, D. J. Palace, B. A. Pasquale, H. L. Peabody, NASA Goddard Space Flight Ctr. (United States); B. S. Smith, Stargazer Systems (United States); W. F. Smith, J. W. Stewart, D. A. Vaughnn, A. Waczynski, T. E. Wallace, NASA Goddard Space Flight Ctr. (United States)

8860 OG A tolerancing approach taking into account the interferometric alignment scheme of the EUCLID NISP space optics [8860-16]

F. Grupp, Max-Planck-Institut für extraterrestrische Physik (Germany) and Univ.-Sternwarte München (Germany); E. Prieto, Aix-Marseille Univ. LAM, CNRS (France); N. Geis, A. Bode, R. Katterloher, C. Bodendorf, Max-Planck-Institut für extraterrestrische Physik (Germany); M. Becker, S. Bogner, Max-Planck-Institut für extraterrestrische Physik (Germany) and Ernst-Abbe Fachhochschule (Germany); R. Bender, Max-Planck-Institut für extraterrestrische Physik (Germany) and Univ.-Sternwarte München (Germany)

\section{SESSION $5 \quad$ INSTRUMENTS AND COMPONENTS}

$8860 \mathrm{OH} \quad$ The relationship between pumped traps and signal loss in buried channel CCDs [8860-37] N. J. Murray, The Open Univ. (United Kingdom); D. J. Burt, e2v technologies plc (United Kingdom); D. Hall, A. D. Holland, The Open Univ. (United Kingdom) 
8860 Ol Point-spread function and photon transfer of a CCD for space-based astronomy [8860-18]

E. A. H. Allanwood, N. J. Murray, K. D. Stefanov, The Open Univ. (United Kingdom);

D. J. Burt, e2v technologies plc (United Kingdom); A. D. Holland, The Open Univ.

(United Kingdom)

8860 0J OSIRIS-REx OCAMS detector assembly characterization [8860-19]

J. Hancock, B. Crowther, M. Whiteley, R. Burt, M. Watson, J. Nelson, Utah State Univ.

(United States); C. Fellows, B. Rizk, E. Kinney-Spano, M. Perry, M. Hunten, The Univ. of Arizona (United States)

8860 OK Multi-level parallel clocking of CCDs for: improving charge transfer efficiency, clearing persistence, clocked anti-blooming, and generating low-noise backgrounds for pumping [8860-20]

N. J. Murray, The Open Univ. (United Kingdom); D. J. Burt, e2v technologies plc

(United Kingdom); A. D. Holland, K. D. Stefanov, J. P. D. Gow, C. MacCormick, B. J. Dryer,

E. A. H. Allanwood, The Open Univ. (United Kingdom)

8860 OM Narrow bandpass steep edge optical filter for the JAST/T80 telescope instrumentation [8860-22]

S. Reichel, SCHOTT AG (Germany); U. Brauneck, S. Bourquin, SCHOTT Suisse SA

(Switzerland); A. Marín-Franch, Centro de Estudios de Fisica del Cosmos de Aragón (Spain)

8860 ON Radiation damage to six selected optical materials [8860-23]

F. Grupp, Max-Planck-Institut für extraterrestrische Physik (Germany) and Univ.-Sternwarte München (Germany); N. Geis, R. Katterloher, Max-Planck-Institut für extraterrestrische Physik (Germany); R. Bender, Max-Planck-Institut für extraterrestrische Physik (Germany) and Univ.-Sternwarte München (Germany)

886000 Benefits of ion milling ULE as compared to glass ceramics [8860-24] J. F. Ellison, G. P. Cox, Corning Fairport (United States) L. J. Sutton, A. C. Fox, Corning Incorporated (United States) T. M. Rich, Corning Fairport (United States); T. A. Sebring, Xoptx LLC (United States)

8860 OP ZERODUR: progress in CTE characterization [8860-25]

R. Jedamzik, C. Kunisch, T. Westerhoff, SCHOTT AG (Germany)

$88600 Q$ Overview and recent accomplishments of the advanced mirror technology development (AMTD) for large aperture UVOIR space telescopes project [8860-26] H. P. Stahl, NASA Marshall Space Flight Ctr. (United States); M. Postman, Space Telescope Science Institute (United States); L. Abplanalp, Exelis Inc. (United States); W. Arnold, Defense Acquisitions Inc. (United States); R. Eng, NASA Marshall Space Flight Ctr. (United States); A. Sivaramakrishnan, Space Telescope Science Institute (United States) 
8860 OU Elimination of linear astigmatism in off-axis three-mirror telescope and its applications [8860-30]

S. Chang, Off-Axis Optics Lab. (Korea, Republic of)

8860 OV Pixel-level modelling and verification for the Euclid VIS CCD [8860-31]

A. Clarke, D. Hall, N. Murray, J. Gow, A. Holland, The Open Univ. (United Kingdom);

D. Burt, e2v technologies plc (United Kingdom)

8860 oW Calibrating apodizer fabrication techniques for high-contrast coronagraphs on segmented and monolithic space telescopes [8860-32]

A. Sivaramakrishnan, Space Telescope Science Institute (United States) and Stony Brook Univ. (United States) and American Museum of Natural History (United States);

A. Z. Greenbaum, Johns Hopkins Univ. (United States); G. L. Carr, R. J. Smith, X. Xi, Brookhaven National Lab. (United States); N. T. Zimmerman, Max-Planck-Institut für Astronomie (Germany)

8860 0X Innovative CCD readout technology for use in large focal plane array development [8860-33]

T. J. Veach, Arizona State Univ. (United States) and NASA Goddard Space Flight Ctr. (United States); P. A. Scowen, Arizona State Univ. (United States)

8860 OY ACCESS: thermal mechanical design and performance [8860-34]

M. E. Kaiser, M. J. Morris, Johns Hopkins Univ. (United States); J. Hansen, Space Dynamics Lab. (United States); S. Jensen, Space Dynamics Lab. (United States) and Utah State Univ. (United States); S. R. McCandliss, Johns Hopkins Univ. (United States); B. J. Rauscher, R. A. Kimble, J. W. Kruk, NASA Goddard Space Flight Ctr. (United States); R. Pelton, Johns Hopkins Univ. (United States); D. Mott, Y. Wen, J. P. Gardner, D. J. Benford, B. E. Woodgate, NASA Goddard Space Flight Ctr. (United States); E. L. Wright, Univ. of California, Los Angeles (United States); P. D. Feldman, H. W. Moos, Johns Hopkins Univ. (United States); A. G. Riess, Johns Hopkins Univ. (United States) and Space Telescope Science Institute (United States); R. Bohlin, S. E. Deustua, W. V. Dixon, D. J. Sahnow, Space Telescope Science Institute (United States); R. Kurucz, Harvard-Smithsonian Ctr. for Astrophysics (United States); M. Lampton, Space Sciences Lab. (United States); S. Perlmutter, Univ. of California, Berkeley (United States)

$88600 \mathrm{Z}$ A design and trial production of the image slicer unit for the mid-infrared spectrograph [8860-35]

I. Sakon, The Univ. of Tokyo (Japan); H. Kataza, Japan Aerospace Exploration Agency (Japan); T. Onaka, The Univ. of Tokyo (Japan); N. Fujishiro, Kyoto Sangyo Univ. (Japan) and Kyoto-Nijikoubou (Japan); Y. Ikeda, Photocoding, Inc. (Japan); H. Tokoro, NanoOptonics Research Institute (Japan); H. Nakagawa, O. Kirino, Crystal Optics (Japan); K. Mitsui, N. Okada, National Astronomical Observatory of Japan (Japan) 
886010 Conceptual opto-mechanical design of a NIR imaging spectrometer for the Korean NEXTSat-1 mission [8860-36]

B. Moon, K. Park, S.-J. Park, W.-S. Jeong, D.-H. Lee, Y. Park, U.-W. Nam, W. Han, J. Pyo, W. Park, I.-J. Kim, Korea Astronomy and Space Science Institute (Korea, Republic of); D.-H. Lee, Korea Astronomy and Space Science Institute (Korea, Republic of) and Univ. of Science and Technology (Korea, Republic of); J.-S. Chae, G.-H. Shin, Korea Advanced Institute of Science and Technology (Korea, Republic of); N. Takeyama, A. Enokuchi, Genesia Corp. (Japan)

886012 Self-induced polarization anisoplanatism [8860-39]

J. B. Breckinridge, California Institute of Technology (United States)

886013 The Geospace Dynamics Observatory: a paradigm changing Geospace mission [8860-40] J. Spann, NASA Marshall Space Flight Ctr. (United States); P. J. Reardon, K. Pitalo, The Univ. of Alabama in Huntsville (United States); P. Stahl, R. Hopkins, NASA Marshall Space Flight Ctr. (United States)

886014 The LBT experience of adaptive secondary mirror operations for routine seeing- and diffraction-limited science operations [8860-41]

J. C. Guerra, Large Binocular Telescope Observatory (United States); G. Brusa, Steward Observatory (United States); J. Christou, D. Miller, Large Binocular Telescope Observatory (United States); A. Ricardi, M. Xompero, R. Briguglio, INAF - Osservatorio Astrofisico di Arcetri (Italy); M. Wagner, M. Lefebvre, Large Binocular Telescope Observatory (United States); R. Sosa, Steward Observatory (United States)

Author Index 


\title{
Conference Committee
}

\author{
Program Track Chair
}

Oswald H. Siegmund, University of California, Berkeley (United States)

\section{Conference Chairs}

Howard A. MacEwen, Reviresco LLC (United States)

James B. Breckinridge, College of Optical Sciences, The University of Arizona (United States) and California Institute of Technology (United States)

\section{Conference Program Committee}

Suzanne Casement, Northrop Grumman Aerospace Systems (United States)

Daniel R. Coulter, Jet Propulsion Laboratory (United States)

Colin R. Cunningham, UK Astronomy Technology Center (United Kingdom)

Lee D. Feinberg, NASA Goddard Space Flight Center (United States)

Matthew J. Griffin, Cardiff University (United Kingdom)

David Leisawitz, NASA Goddard Space Flight Center (United States)

Jean-Pierre Maillard, Institut d'Astrophysique de Paris (France)

Gary W. Matthews, Exelis Geospatial Systems (United States)

Mark J. McCaughrean, European Space Research and Technology Center (Netherlands)

Jacobus M. Oschmann Jr., Ball Aerospace \& Technologies Corporation (United States)

Marc Postman, Space Telescope Science Institute (United States)

Steven H. Pravdo, Jet Propulsion Laboratory (United States)

H. Philip Stahl, NASA Marshall Space Flight Center (United States)

Session Chairs

1 JWST

Howard A. MacEwen, Reviresco LLC (United States)

2 Large UVOIR Space Telescopes

Suzanne Casement, Northrop Grumman Aerospace Systems (United States)

3 Space Telescope Concepts

James B. Breckinridge, College of Optical Sciences, The University of Arizona (United States) and California Institute of Technology (United States) 
4 WFIRST/EUCLID

H. Philip Stahl, NASA Marshall Space Flight Center (United States)

5 Instruments and Components

Jacobus M. Oschmann Jr., Ball Aerospace \& Technologies Corporation (United States)

6 Materials for Space Telescopes: Joint Session with Conferences 8837 and 8860

Howard A. MacEwen, Reviresco LLC (United States) 


\section{Introduction}

This two-day conference included a total of approximately forty papers and was organized into six separate topic sessions'. These topics were supported in some particular details by papers presented in the Poster Session on the evening of the second day. In turn, the six topics were arranged under three major discussion areas: status reports concerning active, programmed systems; concepts for future systems (especially when they are likely to be candidates for consideration in the National Academies 2020 Astronomy and Astrophysics Decadal Survey); and technologies for both sensors and for telescope and spacecraft subsystems and components. In detail:

1. Programmed Systems. Only one system, the James Webb Space Telescope (JWST) is sufficiently advanced in development for this session. The session was organized around an invited paper that described an overview of the status of the program, which was then amplified with a paper on the JWST science drivers, a status report on the build-up of the Integrated Science Instrument Module (ISIM), and a detailed paper on a noise reduction problem in one of the instruments. Specific status reports were not provided on the individual instruments, since there have only been minor changes since those reports were provided in detail in the 2012 Astronomical Instruments and Telescopes Conference in Amsterdam.

2. Future System Concepts. As was to be expected, this section was considerably more diverse than the preceding. Several sub-topics were included:

- WFIRST/EUCLID. Recent mission and preliminary design studies ${ }^{2}$ for using the recently donated 2.4 meter telescopes were presented in overview in this section, and a specific approach to developing design tolerances for the ESA EUCLID concept was provided.

- Space Telescope Concepts and Operations. A number of concepts were outlined under this heading, including small cameras, small spectroscopic survey satellites, to 4 meter (and larger) UV-Visible-IR space telescopes. Taken as a whole, most of the optical spectrum was considered in this general section, and major structural elements (specifically light shields) and possible interactions with the infrastructures needed to support NASA human exploration missions were discussed.

3. Technologies. This section addressed:

- Sensor and detector arrays, including aspects such as radiation damage, clocking, coatings, and filters.

${ }^{1}$ Note that the sixth and final session was joint with Conference 8837: Materials for Space Telescopes.

2 There were also significant discussions of these telescopes and their application to Exo-planet

research in Conference 8864, Session 8. 
- Materials for space telescopes, presented in a Joint Session with Conference 8837 on materials technologies and applications. Specific topics included market potential, processing for mirrors, and radiation damage.

- The Conference concluded with an overview of the NASA Advanced Mirror and Technology Development (AMTD) program, which is developing several specific (and related) technologies that can be used as foundations for future UVOIR space telescope systems. The intent is to ensure that all critical technologies have achieved at least TRL 6 in time for the 2020 Decadal Survey.

Howard A. MacEwen James B. Breckinridge 